\section{Intersections}

Canadian Journal of Music

Revue canadienne de musique
Intersections CANADIAN JOURAL OF MUSIC
REVUE CANADIENEE DE MUSIOUH

\title{
Musical Washing Machines, Composer-Performers, and Other Blurring Boundaries: How Women Make a Difference in Electroacoustic Music
}

\section{Hannah Bosma}

Volume 26, numéro 2, 2006

In and Out of the Sound Studio

URI : https://id.erudit.org/iderudit/1013229ar

DOI : https://doi.org/10.7202/1013229ar

Aller au sommaire du numéro

Éditeur(s)

Canadian University Music Society / Société de musique des universités canadiennes

ISSN

1911-0146 (imprimé)

1918-512X (numérique)

Découvrir la revue

Citer cet article

Bosma, H. (2006). Musical Washing Machines, Composer-Performers, and Other Blurring Boundaries: How Women Make a Difference in Electroacoustic Music. Intersections, 26(2), 97-117. https://doi.org/10.7202/1013229ar

\section{Résumé de l'article}

Cet essai explore les possibilités et limites dune écriture féminine musicale dans la musique électroacoustique. Les théories de Cox, Dame et Citron sur la " musique des femmes » sont discutés en parallèle avec les travaux de McCartney et Hinkle-Turner sur les compositrices électroacoustiques et les analyses d'œuvres de Rudow, Isadora et LaBerge. Rétablissement de rapports sociaux de genres pour les catégories musicales est analysé par l'exemple de l'opération d'appropriation de la " voix » de Cathy Berberian par Berio. Des stratégies de déstabilisation de catégories musicales sexuées sont ici étudiées, par exemple le contenu féminin/féministe, les compositrices/interprètes, l'interdisciplinarité et la collaboration. Le caractère interdisciplinaire de plusieurs oeuvres de femmes peut entraver sa documentation et, de ce fait, sa pérennité. La recherche de l'auteure, réalisée à NEAR/Donemus, porte spécialement sur ce problème.
Copyright @ Canadian University Music Society / Société de musique des universités canadiennes, 2007
Ce document est protégé par la loi sur le droit d'auteur. L’utilisation des services d’Érudit (y compris la reproduction) est assujettie à sa politique d'utilisation que vous pouvez consulter en ligne.

https://apropos.erudit.org/fr/usagers/politique-dutilisation/ 


\section{Musical Washing Machines, Composer-Performers, AND OTHER BLURRING BOUNDARIES: HOW WOMEN MAKE a Difference in Electroacoustic Music ${ }^{1}$}

\section{Hannah Bosma}

Can we define a "women's music" in the field of electroacoustic composition? While Joke Dame (1994, 23-25) notes that feminist musicology is at an impasse regarding the questions of the specific femininity of women's compositions and of the difference between compositions by women and men, she also suggests the possibility of an écriture féminine musicale, that shows resemblances with the French literary movement of écriture féminine. ${ }^{2}$ In this essay I examine écriture féminine musicale in relation to electroacoustic music, considering several studies of women composers in the field.

But how important is the gender of the composer? Listeners' response theory (Dame 1994, 45-65) does away with the authority of the composer, following Roland Barthes' "The Death of the Author," to make room for interpretations that do not seek to follow the intentions of the composer. Such an attitude results in a wealth of interesting alternative analyses and interpretations of (often metaphorical) "feminine voices" in canonical musical works by male composers (e.g., Abbate 1993, Dame 1994), but at the risk of continuing the negligence of musical works created by women. How to search for women's music while taking into account the de-centralization of the author?

In this paper, I discuss and critique ideas of "women's music" while looking for feminine and feminist tendencies in electro-acoustic music. I point to some of the consequent problems of such ways of working and offer a concrete suggestion for preserving such music while simultaneously opening it up for reinterpretation and wider dissemination.

\section{ÉCRITURE FÉMININE MUSICALE}

The idea of a specific "women's music" is by no means new. Marcia Citron's overview of ideas about women's music by several composers and theorists refers to gender differences in genre, style, and compositional process (1993,

1 This article is based on a lecture at the conference In and Out of the Studio at Concordia University in Montréal, July 27,2005; it is an elaboration of several ideas presented in a paper at the conference Feminist Theory and Music 4 at the University of Virginia, Charlottesville VA, 1997.

I thank the editors for their thorough comments and linguistic corrections, and Andra McCartney for the invitation to the conference In and Out of the Studio and for all her work in this field.

2 Ecriture féminine is "experimental writing [...] whose impulse is to inscribe femininity" that originated in the 1970s in France, with prolific writers such as Hélène Cixous (Guild 1992: 74). 
120-132, 159-164). For example, she notes that small-scale chamber or salon works have historically been gendered feminine, while complex, large-scale works such as symphonies and operas have been gendered masculine. Similarly, she describes a feminine approach to style (the use of organic, evolving material, more fluid, lyrical and non-hierarchical heterophony) and compositional process (such as a fascination with process rather than a fetishization of originality, and flexibility instead of a reliance on systems). In his 1977 compilation of electroacoustic recordings of women composers (re-released on CD in 1997, CRI 728), Charles Amirkhanian suggested that there was a relation between the emergence of women composers and the rise of an open, "free-wheeling," more "listenable," and non-academic avant-garde electronic music, with a mix of media and sonic materials and a sense of humor, a style that is influenced by non-western and popular music as well as by extra-musical concerns. Beverly Grigsby (1984) stresses the great variety of approaches by North American women composers of electroacoustic music, but discerns a common aesthetic among many: a movement away from academia toward a more accessible or communicative style through participatory pieces or commercial work; inspiration by nature, as well as healing practices and meditation involving an interest in timbral changes; and the combination of electronics with other media. ${ }^{3}$ Finally, Hinkle-Turner finds that women often use sound technology in order to compose with natural and environmental sounds as well as texts, and that they often work with multimedia $(2006,250)$. Hinkle-Turner notes "a dichotomy of 'boys with their toys' and 'girls with their tools"': women use technology because it enables them to realize their compositional ideas, men more often play with technology for its own sake $e^{4}(250-1)$.

In "Recovering Jouissance: An Introduction to Feminist Musical Aesthetics," Renée Cox proposes that the literary style of écriture féminine could serve as a model for the development of a "women's music", that is "expressive of women's experience" $(1991,333) .{ }^{5}$ Cox emphasizes that such "women's music" is not an

3 I would like to point out that the features mentioned by Amirkhanian and Grigsby can be found in music by male composers too; their articulation of women's musical styles and practices suggests a relation between the postmodern turn away from absolute music and the emergence of the women's movement. A discussion of this complex relationship is beyond the scope of this paper to address, but certainly deserves further consideration.

4 This idea is also expressed by Canadian composers Hildegard Westerkamp, Elma Miller and Ann Southam in McCartney 1997, 62-3.

5 See Guild (1992) and Moi (1985) for the highly complex and contradictory notion of écriture féminine, that has both essentialist and deconstructionist aspects. See also Braidotti (1990). Ecriture féminine was developed in the '70s and '80s of the previous century, mainly in France, by a loose group of female writers who were trying to find a female or feminine way of writing (Guild 1992). They elaborated on aspects that are traditionally, stereotypically considered as feminine. The concept of écriture féminine is therefore often criticized as reinforcing traditional, sexist stereotypes such as woman as irrational, excessive, bodily, sexual, governed by the cycles of nature, giving birth and nurturing children. However, écriture féminine is also a disruption of conventional meaning and culture, or even a subversion of such patriarchal dualisms. Indeed, Hélène Cixous, the main proponent of écriture féminine, rejects the term "écriture féminine" as being imprisoned in the binary logic of masculinity vs. femininity. Moreover, Cixous also warns that it is not the sex of the author that makes the writing feminine or masculine (Moi 1985, 108). "It is a question of the feminine process and practice of writing, even though the nature of the feminine remains an open question" (Guild 1992: 74). Écriture féminine 
empirical description of the music that female composers actually make, but an ideal for women who seek to develop a specific women's music instead of trying to fit in with the male-dominated music culture. "Women's cultures are for those who feel that the present culture is not conducive to what they have to offer or express, and that an examination of female experiences may help them to develop different, more authentic voices." (333) Cox characterizes music that is modeled on écriture féminine as music that engages the listener more in the musical moment than in the structure as a whole. Such feminine music would have a flexible, cyclical form and would involve continuous repetition with variation; it would serve to deconstruct musical hierarchies, to disrupt linearity, and to avoid definitive closure (334). As one example, Cox proposes Pauline Oliveros because of her preoccupation with circles, cycles and mandalas. ${ }^{6}$

Cox states that "feminine" musical traits such as musical organicism can also be found in music by men, and that a feminine style is not found in all music by women; however, because women give birth to and nurture children, Cox finds these musical characteristics especially meaningful for women. Moreover, Cox argues that her description of the feminine is similar to patriarchal constructions of femininity, because women are influenced by such patriarchal constructions. Instead of the patriarchal oppression of the feminine she pleas for a revaluation of the feminine. She argues that the female body, sexuality, and emotions have vital importance for the integration of body and psyche, of art and life, which potentially disrupts the patriarchal order. $(1991,337)$ "Such integration can give rise to authenticity and creativity, a special kind of creativity concerned not with the production of aesthetic objects but with living a life aesthetically, with the integration of art and life". (337)

For Cox, vocal music modeled on écriture féminine would make use of nonverbal, pre-symbolic vocal sounds. The pre-symbolic voice is associated with femininity because of the importance of the mother's voice for the young child, "the rhythmic, pre-symbolic play of mother-infant communication" (1991, 334), and because of the greater and longer connection of girls with their mothers since they have the same gender identity.

There are several problems with Cox's articulation of "women's music." In the first place, it reinforces traditional stereotypes of femininity. Cox acknowledges this, but argues that we cannot avoid the influence of patriarchal constructions

has both essentialist and deconstructionist aspects. Julia Kristeva is also often associated with the notion of écriture féminine, and both Cox (1991) and Dame (1994) elaborate on her ideas of the pre-symbolic, "semiotic," non-verbal aspects of the voice. However, Kristeva challenges the very notion of identity and therefore rejects the idea of écriture féminine as inherently womanly: "Nothing in women's past or present publications seems to allow us to affirm that there is a feminine writing" (Kristeva cited in Moi 1985, 163 ) and "woman as such does not exist" (Kristeva cited in Moi 1985, 165). For Kristeva, femininity is "that which is marginalized by the patriarchal symbolic order" (Moi 1985, 166) and is therefore a shifting category and context dependent. To assign "femininity" to musical features per se, such as cyclical form or non-verbal voice sounds, is opposite to such a deconstructive conception of écriture féminine. Radical is not "expressive of women's experience," but a play with signs.

6 Some of the other examples mentioned by Cox are: Ellen Taafe Zwilich, whose music is characterised by the cyclic principle, as well as by continuous organic growth and variation (336); and Kay Gardner, who compares the circular musical form with women's sexual experience, with the climax in the middle rather than at the end (335). 
of femininity; however, whereas patriarchy values femininity as negative and uses this to oppress women, Cox pleads for a positive revaluation of femininity.

"Perhaps the most difficult problem with the idea of a women's music lies in determining how to distinguish the expression of women's experience from the expression of male constructions of the feminine. [...] Rather than attempt to separate themselves completely from male concepts of the feminine, undoubtedly an impossible task, feminists could expose these concepts or images and reformulate them in a positive light." $(1991,337-8)$

Moreover, Cox explains that feminine musical characteristics could function in different ways depending on the context; for example, misogynist (Wagner's Tristan und Isolde) or feminist (Laurie Anderson's Langue d'Amour). The determination of feminine musical traits could be used in feminist critical musical analysis: "Whether or not the feminist critic finds generalizations about the feminine or women's experience productive or oppressive, a feminist approach could identify, explicate, and critique such perspectives." (Cox 1991, 338)

My critique of Cox's perspective is twofold. One problem is that she overlooks the "masculine" features in some of her examples of women's music; for example, the importance of music technology in the work of Pauline Oliveros and Laurie Anderson. A second problem is that her "women's music" contains features that are characteristic of much avant-garde music by male composers. Cyclic and flexible forms have been explored abundantly by the male-dominated musical avant-garde of the Twentieth century, as well as the disruption of linearity and the avoidance of definitive closure. Continuous repetition with variation is the basis of the minimal and repetitive music of Terry Riley and Steve Reich. The emphasis on the musical moment was explored by Karlheinz Stockhausen with his "moment form" of compositions like Momente (1961-4). I consider Cox's plea for "women's music" to be an appropriative gesture: to claim musical features of the male-dominated avant-garde for women's music. ${ }^{7}$

Is there a specifically womanly style in music and musical performance? Most female composers are very reluctant to generalize, as Andra McCartney found in her research on Canadian women composers of electroacoustic music:

None of my consultants wishes to define an essential difference in sound between electroacoustic music composed by men and music by women, whether marked by dynamics, form, or any other musical element. However, several say that these differences might exist, because women's experiences and socialization are different from those of men. Both Pascale Trudel and Gayle Young comment on how women's music is expected to be gentler and softer, yet this was not a generalization that held true in their own music, or others.' $(1997,171)$

7 It also points, again, to a coincidence of postmodernism and feminism, but also to the complex relation of these movements. 
Yet, McCartney notes, there is a desire for women composers neither to conform to the male-dominated prevalent musical style, nor to adhere to stereotypes of femininity:

A woman composer then faces a difficult challenge: how can she express herself musically, as a woman, without confirming the stereotypes of femininity which have been associated with Woman in western music? [...] $[W]$ ithout sounding like Man, using malestream musical forms and techniques, or sounding like stereotypical Woman? What does feminist music sound like?" $(1997,178)$

McCartney's analysis demonstrates that electroacoustic music is gendered as stereotypically male both with regard to gender symbolism (masculine and sexist terminology, metaphors and images) and gender structure (social structure or division of labor: women are a minority in electroacoustic music as students and teachers, in receiving grants, as composers of works performed at concerts, on conferences, etc.). ${ }^{8}$ Electroacoustic music is thus a culmination of two male domains, composition and technology.

McCartney found that most of the women composers she interviewed felt alienated by the emphasis on masculinity in the electroacoustic world, and that they developed different strategies to cope with this. Although there were many differences with regard to the instrument choices, compositional techniques, and the music of the women composers, McCartney found some common themes. These included a preference for working with recorded sound (sampling); humor and parody; improvisational, interactive or non-linear compositional approaches; a focus on women's stories, and the evocation of listeners' memories. Inspired by the work of Donna Haraway in her search for a feminist cyborg music, McCartney found electroacoustic practices and compositions of women composers that suggest alternative "worlds" and in which gendered binary opposites (such as mind and body, technology and nature, composition and performance, control and letting go) integrate or disperse into multiple differences.

Lucy Green (1997) argues that composing is connoted ("delineated") as masculine, both by the association with mind, autonomy and creativity, and by the fact that the overwhelming majority of composers that most people know of (via education, radio, etc.), are male. The masculine connotation of the composer is so self-evident, that it is mostly not even consciously noticed.

Music delineates masculinity, a male mind, a man behind the music; and this has become so normal and acceptable that we do not even notice its presence, until something happens to break it. The masculine meaning of music arises partly by virtue of the clash between the bodily connotations of femininity and the cerebral delineations of composition; it also arises by virtue of the minority status of women in-and even, in some types

8 "Gender symbolism" and "gender structure" are concepts articulated by Sandra Harding, 1986. See also McCartney 1995. 
of music, their exclusion from-the role of composer. In a relationship of circularity, it is then used to justify that exclusion. (114)

A female composer is thus perceived as abnormal. She interrupts the status quo and threatens normative (mostly unconscious) ideas about music. Because composition is gendered male, her femininity is called into question. Green argues that this has a negative influence on the musical experience, both for the listener and for the composer herself. "Is there any possibility of an alternative to the normality of the masculine delineation of music, and its near hegemony over our experiences?" she asks $(1997,138)$.

Green's solution is paradoxical. She suggests that masculine delineations may best be disrupted by explicit feminist references, or by the emphatic positive presence of strong women musicians (whether composers, improvisers, instrumentalists or singers). But while she expects that these interruptive delineations might negatively affect the listening experience, she hopes that a fulfilling experience of the music itself (of its "inherent meanings") will cause the listener to re-evaluate the disruptive, interruptive or threatening qualities of the feminine delineation and thus to re-evaluate the listener's assumptions about both the gender-related characteristics of music and about femininity. Somehow, the "music itself" must be so excellent and convincing that the very strong habit of perceiving a female composer and her music as disruptive will be overcome. Thus Green notes: "Such a re-evaluation of the interruptive or threatening effects of feminine delineations is hard to achieve and rare." $(1997,139)$ Green's "solution" amounts to the adage that to gain acceptance, to have success, women must produce much better results and work much harder than men, and that only excellent achievements of women will pass through the sieve of cultural valuation.

I envision a somewhat different solution to the negative influence of the masculine connotation of composition. In the first place, I do not take for granted that all women completely identify with, or strive for, conventional femininity-nor that all men expect or desire women to be conventionally feminine. Some women identify (partly) with masculinity or with men, and some women identify with different models of womanliness, with unconventional womensuch as women composers. In the case of electroacoustic music, studies have demonstrated the importance of such role models, as the following two quotations demonstrate.

"I find the music and the stories of these [women] composers [of electroacoustic music] to be inspiring. Others do, too. Every time I give a presentation on this study, at least one woman comes forward afterward and confesses that she had almost given up on studio work, but that hearing these stories has given her the courage and motivation to continue." (McCartney 1996, 45)

"This search for a professional role model in my own life is what initially led me to study the work and achievements of many contemporary women composers and since my primary area of creative interest was in electroacoustic music, it was natural that my research led me to women in this 
particular field. [...] I have become well-acquainted with so many successful women composers utilizing music technology that I find no end of encouragement and inspiration. [...] It is my hope that Women Composers and Electroacoustic Music in the United States: Crossing the Line will serve a similar purpose to other ambitious women in the arts." (Hinkle-Turner 2006, 8)

While Green considers gender connotations of music mainly as a hindrance to the valuation of "the music itself," I would like to suggest that a positive identification with female figures in music, can stimulate new forms of musical appreciation, of listening, analyzing, performing and composing. So instead of Green's ideal of excellent music that overcomes the negative connotations attached to the female composer, I think it is possible that, at least for some women, a connotation of unconventional womanliness can function as a positive appeal to the music and as an incentive to pay attention to the composition. Then, the female connotation does not hinder but stimulates the perception of the music.

\section{VoICES, AUThors AND Singers}

Joke Dame (1994: 25) outlines an écriture féminine musicale based on Elizabeth Guild's description of écriture féminine $e^{9}$ (in Wright 1992: 75) which Dame relates to Kristeva's notion of the "semiotic": the rhythms, timbres and inflections of the voice, the playful, unsettling disruption of language. ${ }^{10}$ As examples of such écriture féminine musicale, Dame proposes the "vocal tradition" of Cathy Berberian, Joan La Barbara, Meredith Monk, Diamanda Galàs, Laurie Anderson, Moniek Toebosch, Greetje Bijma and Jannie Pranger (Dame 1994: 25). Dame refers also to the music of Luciano Berio and John Cage. Unfortunately, Dame does not elaborate on these examples. In response, I touch on the following questions: Is the gender of the composer relevant for a description of music as écriture féminine? How "feminine" is the work of the above mentioned vocalists?

9 “The linguistic horizon of these texts is a writing which some describe as closer to the (mother's) voice, to the flesh and rhythm of our earliest awareness of language than is conventional writing [...]. The texts are characterized by play, disruption, excess, gaps, grammatical and syntactic subversion, ambiguities; by endlessly shifting register, generic transgressions; by fluid figurative language and myths. They are anti-authoritarian, questioning, unsettling." (Guild 1992: 75).

${ }_{10}$ Moi argues that Kristeva does not consider the semiotic as feminine, because in this realm the opposition between feminine and masculine does not exist. "The claim [...] that Kristeva associates the semiotic with the feminine is thus based on a misreading. [...] Any strengthening of the semiotic, which knows no sexual difference, must therefore lead to a weakening of traditional gender divisions, and not at all to a reinforcement of traditional notions of 'femininity"' (1985, 165) The link between the semiotic and femininity however, is that Kristeva considers both as marginal to the symbolic order. Kristeva's own analyses of the semiotic in literature and poetry are mainly concerned with works by male authors. Kristeva suggests that it may be dangerous for women to focus on the semiotic. "When he flees the symbolic paternal order [...], man can laugh. [...] But [...] the invasion of her speech by these unphrased, nonsensical, maternal rhythms, far from soothing her, or making her laugh, destroys her symbolic armour and makes her ecstatic, nostalgic or mad [...] A woman has nothing to laugh about when the symbolic order collapses." (Julia Kristeva 1974, "About Chinese Women" in Moi 1986, 150) See also Silverman 1988 and Braidotti 1990. 
Berio's tape composition Thema (Omaggio a Joyce) $(1958)^{11}$ manipulates a recording of Cathy Berberian reading the opening of the $11^{\text {th }}$ chapter (the "Siren chapter") of James Joyce's Ulysses. The particular sound of Berberian's voice is very characteristic of this piece. Thema (Omaggio a Joyce) is full of unconventional, non-linguistic female vocal sounds. Would Thema (Omaggio a Joyce) be a good example of écriture féminine in electroacoustic music? Does it exceed binary logic and disrupt patriarchal order, as écriture féminine $e^{12}$ claims to do? I find it necessary not only to consider the voice, but also the issue of authorship. Although Berberian's particular voice and creativity are indissolubly part of the tape-compositions Thema (Omaggio a Joyce) and Visage (1961), these compositions are known as "composed by Berio." In many texts (liner notes and analyses) about Thema (Omaggio a Joyce), Berberian is not even mentioned; especially in Berio's own article about the piece, Berberian's particular, impressive voice is reduced to anonymous linguistic material, a neutral extension of the written text. ${ }^{13}$ The title of the piece-Omaggio a Joyce-and the compositional procedure as described by Berio suggest that, with this piece, Berio places himself in the tradition of author James Joyce and of the modernist avant-garde. Berberian's work was appropriated by Berio, and in his acknowledgments her voice is a suppressed Other. A patrilineal descent ${ }^{14}$ is suggested, ignoring the woman. Stereotypically, the female voice is presented as "sound material," and the male composer, who orders this material, is considered the authoritative creator. ${ }^{15}$

Both Berio and Cage were greatly influenced by Cathy Berberian in their compositions for female voice. Berberian's innovations included: her unconventional use of the voice, her performance of nonmusical vocal sounds as well as a wide range of singing styles, and her development of a new concept of performance that combined musical and theatrical elements, irony and playfulness, high and low culture. Both Berio and Cage made compositions for her based on the vocal possibilities she developed and demonstrated. ${ }^{16}$ The vocal art of Cathy Berberian was an inspiration for many avant-garde female vocalists, who are not only singers, but also composers of their own vocal work, such as: Joan La Barbara, Diamanda Galás, Shelley Hirsch, Greetje Bijma, Kristin Norderval, Franziska Baumann and Pamela Z. These composer-vocalists take both the masculine position of composer (determining structure) and the feminine position as vocalist (producing vocal sound). ${ }^{17}$

${ }^{11}$ A stereo recording, digitized and re-edited in 1995 under supervision of Luciano Berio, is published on the CD Luciano Berio-Many More Voices, BMG 09026-68302-2 (1998).

${ }_{12}$ See Guild 1992 and Moi 1985.

13 Berio 1959; this article seems to be the basis of many texts by others on this composition.

14 This patrilineal descent not only includes Joyce and Berio, but also the male listener/analyst who uncritically follows Berio's intentions, composition techniques and ideas, and relates these directly to Joyce's text; e.g. Di Scipio 2005, Dreßen 1982.

${ }_{15}$ See also Bosma 1996, 1997, 1998a, 1998b, 2006.

16 See Vila 2003. The influence was both ways. David Osmond-Smith elaborated on the strong interplay between Berio/Cage and Berberian in his keynote lecture at the conference Cathy Berberian: Pioneer of Contemporary Vocality and Performance, April 27, 2006, University of Amsterdam.

${ }^{17}$ For the gender pattern of male composers and female vocalists in electroacoustic music, see Bosma 2003. 
The breaking-up of language and the use of non-verbal vocal sounds is an established practice in the predominantly male musical avant-garde, for example in music by Luciano Berio, György Ligeti, Dieter Schnebel, and others. Moreover, breaking up language is also the most significant device of the conspicuously male tradition of sound poetry; for example, the works of Dadaists like Hugo Ball and Kurt Schwitters and of contemporary artists like Jaap Blonk. The avant-garde composers splice language and leave the realization in sound to others; the sound poets stutter and cry; but the female vocalist-composers mostly sing in many different ways. ${ }^{18}$ Singing is a feminine practice: ${ }^{19}$ it is affirmative of femininity, as Green argues, because of the involvement of the body, the display on stage, its non-technological nature, and its association with the mother/whore dichotomy.

From the sixteenth right through to the twentieth century, it is no exaggeration to say that singing has continued to represent by far the greatest musical performance opportunity available to women, in both the amateur, domestic sphere and the professional, public sphere. $(1997,33)$

But instead of submitting to the traditional cultural rules of singing, these vocalist-composers extend and develop the practice of singing. By composing with their innovative voice sounds, vocalizing has become, explicitly, creating.

Neither Cox (1991) nor Dame (1994) mention that these female vocalistcomposers work with sound technology for composing and authoring their vocal works. Vocalist-composers use recording, amplifying and sound processing for the manipulation of their voice sounds, for structuring and composing, for performance, and for fixing the composition and disseminating it. They are seen on stage mastering technological equipment. ${ }^{20}$ When one adheres to traditional notions of femininity as bodily, unmediated, and natural, the importance of electronic sound technology for processing, composing, and disseminating their voices seems at odds with the supposed femininity of these women's work. Thus, they combine feminine cultural practices of singing and performance with the masculine cultural domains of the avant-garde, authorship, composing, and technology.

\section{FEMINIST STORIES}

In contradiction to the notion of écriture féminine musicale as mainly non-verbal and pre-linguistic, text and technology are important elements in the work of many female composer-performers, such as Laurie Anderson, Diamanda Galás, Shelley Hirsch, and Laetitia Sonami. The focus on stories is also common in the work of Canadian women who compose electroacoustic music (McCartney 1997, 171; McCartney 1996, 44). In several electroacoustic compositions by women composers, there are explicit references to feminine and feminist

18 See also Weber-Lucks 2003.

19 See also Cusick 1999.

20 For an account of the role of technology in the work of Laurie Anderson, see McClary 1991 (132-147). 
issues. ${ }^{21}$ Such work creates new spaces for women's practices in the symbolic order and unsettles traditional gendered dichotomies, not by disrupting but by changing the symbolic.

For example, in the liner notes of the composition With Love (1986) ${ }^{22}$ for violoncello and tape, composer Vivian Adelberg Rudow (USA) ${ }^{23}$ explains how this composition relates to the feminine issue of motherhood. In some performances, loudspeakers are placed in two decorated cello cases: one is called "Electronic Woman," the other "Electronic Mom." On the tape part, there are voices of twenty-three people talking about their mothers or about being a mother ("Electronic Mom"), in addition to newly composed music ("Electronic Woman") and fragments of older pieces by the composer. The only non-verbal cry in With Love is a baby's cry, and there are a few non-verbal voice sounds from a male voice. In this piece, women, including mothers, are not associated with non-verbal sounds and the pre-symbolic realm. Instead, mothers are described as being very capable of adult activities like hiking, driving, cooking, and being an artist. They have adult speaking voices. The text suggests that one can find particular inherited traces of one's own mother in oneself, whether one is male or female. This idea seems to be paralleled by the composer's idea of re-using recorded fragments from her older compositions. Thus, sound technology is used for recording and re-playing, intermingling of elements from different times and different origins, and combining different voices.

Hoofdwas (1995), by Alison Isadora (NZ/NL) ${ }^{24}$ for mezzo soprano, MIDI washing machine and live electronics, features vocalist Jannie Pranger who sings and speaks texts about clothes washing and about Mary Watson who traveled through the New-Zealand countryside in the 1930's on a motorcycle equipped with a sidecar in which a washing machine was placed. Watson visited families in the outback in order to do their washing. On stage the singer operates a washing machine, whose sound is electronically amplified and processed. At the same time she practices singing exercises, and talks about how good it is to combine singing with washing. Different stages of the washing process can be used for different stages of singing practice, like warming up the voice, or learning a melody or text. Here, non-verbal voice sounds are not presented as excessive, absolute, abstract or pre-linguistic, but as part of the cultural practice of singing. To combine washing and singing exercises in a stage performance subverts the division of the private and the public realm.

21 See McCartney (1997) and Hinkle-Turner (2006) for many works by women composers with explicit feminine or feminist references; in Hinkle-Turner (2006) for example: rewriting the stories of Hera (by Jean Eichelberger Ivey) or Euridice (by Anne LeBaron), or composing-performing with "Lady's gloves" as MIDI-interfaces, initially made from rubber kitchen gloves, the "'perfect housewife's tools"' (by Laetitia Sonami).

${ }_{22}$ In the CD Cultures Electroniques 3, Bourges 1988 Lauréats, $16^{\mathrm{e}}$ Concours International de Musique Electroacoustique, LDC 278046 (Le Chant du Monde); With Love won a first prize in this competition.

${ }^{23}$ For more information on Vivian Adelberg Rudow, see her website <http://www. vivianadelbergrudow.com/>.

24 For information on Alison Isadora, see <http://www.donemus.nl >. 
Another example of electroacoustic music featuring a narrative about women and technology is Drive (2003) by Anne La Berge (NL/USA). ${ }^{25}$ This piece has several different forms: it is a concert piece for soloist or ensemble with structured improvisation, pre-recorded sounds and live-electronics, and there is also a version for an installation. The piece is performed by Anne La Berge herself (flute and electronics), as well as by others. As prerecorded sound, we hear a recorded woman's voice ("Mary Anderson," a persona based on the historical American Mary Anderson, circa 1900). Anderson tells us how she invented and patented the windshield wiper, ${ }^{26}$ and how this relates to her experiences and fantasies of the female anatomy, such as the cleansing process of menstruation; thus a strange link between body and technology is created. In Anne La Berge's own solo performance (February 2, 2004, STEIM/Frascati, Amsterdam), she was clearly bodily involved with the sound technology, with her virtuosic bodily performance on her electronically enhanced flute, playing foot pedals, in a dialogue with the recorded voice, etc. The score of Drive gives the performers instructions for improvisation and is structured according to an imaginary vertical time line, more as a written text, instead of the horizontal time line of the traditional musical score, so that the performers are encouraged to integrate music and story. In Drive, the conventional dichotomy of composer-performer is abandoned in favour of plural subject positions: composer, improviser, performance by the composer and/or by others, or without performers as an installation, forging links between bodies and technologies on different levels.

\section{Changing Roles and Crossing Categories}

Many women involved in electroacoustic music combine and integrate composition and performance, and acoustic sound and electronics. ${ }^{27}$ Green (1997) argues that performance as such, and solo musical performance of small instruments like flute and violin as well as the piano, are mostly affirmative of femininity, whereas composition, improvisation, and technology have strong masculine delineations and thus threaten patriarchal femininity. These women composer-performers develop activities in the masculine domains of composition, improvisation, and technology without giving up their activity in the feminine domain of performance, and thus integrate and disperse these gendered binary opposites. 28

Significantly, the roles of composer and performer sometimes seem at odds. Alison Isadora ${ }^{29}$ at one time felt that the combination of composing and performing was not advantageous, and that to be taken more seriously as a com-

${ }^{25}$ For information on Anne La Berge, see <http://www.annelaberge.com/>.

${ }^{26}$ For the historical account, see <http://inventors.about.com/library/inventors/blanderson. $\mathrm{htm}>$

${ }^{27}$ This is confirmed by Hinkle-Turner's (2006) study of North-American women composers of electroacoustic music.

${ }^{28}$ See Metzelaar 2004 for an account of gender issues in the Dutch electroacoustic improvisation scene and the Kraakgeluiden concert series in Amsterdam that was co-founded by Anne La Berge. Metzelaar provides much evidence that improvisation and technology are male fields. zelaar 2004).

Alison Isadora considers herself a "composing performer and a performing composer" (Met- 
poser, she had better stop performing on the violin; however, she didn't, because musical performance is for her a crucial aspect of her musical experience and enjoyment. Alison Isadora remarks:

$[\ldots]$ there were a number of occasions that I recognized that I was not being taken seriously as a composer despite having studied in The Hague and having received distinction there, because of also being a performer. Colleagues only ever enquire about my performances not my compositional work [...]. I wonder how much of this also has to do with being a woman, or at least it seems to me that this is another factor which makes it more difficult ... ${ }^{30}$

Women in the electroacoustic music field do not only combine different musical roles, with different gender connotations, but they also often cross established categories of media, disciplines and genres, combining music, theatre, literature, performance art, visual art, new media, technology, sound documentary, radio art, etc. This was one of the main points that came up in a meeting on women and music technology in the Netherlands, ${ }^{31}$ where 21 women discussed gender issues in relation to their work with music and technology. Most of these women combined different musical roles and different artistic fields in their work, and they had the impression that men's work is less interdisciplinary than women's. Moreover, they felt that their interdisciplinarity is a problem for funding, because funds are often focused on one particular discipline, and that this might be a reason why women receive less funding than men. This is in line with Citron's remark that "in practice many works that do not fit accepted generic categories have suffered oblivion, neglect, or devaluation because of their differences from the established categories" $(1993,125)$. Anne La Berge has said that: "The interdisciplinary nature of our work makes it more vulnerable. There is a developing need for programmers who are committed to interdisciplinary art works with their fuzzy boundaries." 32

But Alison Isadora warns against the danger that all such new forms of music are discarded under the label of "interdisciplinarity", instead of the boundaries of "music" being stretched:

Regarding interdisciplinary work, it seems to me that music is the most exclusive artistic community-in terms of what will be considered music. Lately I've been wondering whether the whole idea of interdisciplinary art

${ }^{30}$ Personal correspondence, e-mail July 20, 2005. Alison Isadora received a composition degree with distinction at the Royal Conservatory in The Hague (Netherlands) in 1994.

${ }_{31}$ I organized this meeting together with the Dutch organization for women and music Stichting Vrouw en Muziek at MuziekGroep Nederland in Amsterdam on February 13, 2004. The participants were female composers, musicians, technicians, organizers and musicologists involved in electroacoustic music: Idske Bakker, Hannah Bosma, Dyane Donck, Cilia Erens, Clare Gallagher, Huba de Graaff, Mariëtte Groot, Ayelet Harpaz, Gloribel Hernandez, Rozalie Hirs, Alison Isadora, Marion de Laat, Anne La Berge, Petra van Langen, Barbara Lüneburg, Helen Metzelaar, Christina Viola Oorebeek, Sylvia Stoetzer, Daniela Swarowsky, Anne Wellmer, and Barbara Woof. A report by Petra van Langen of this meeting was published in the electronic newsletter of Stichting Vrouw en Muziek and can be found on <http:// www.vrouwenmuziek.nl/> (in Dutch).

${ }^{32}$ Personal correspondence, e-mail, July 19, 2005. 
doesn't let the specific art forms off the hook a little too lightly-anything that threatens the status quo of what an art form should be gets shunted off down the interdisciplinary track. Maybe we should still be calling these pieces we are making, that include other art forms but are sound-based, music and maybe the definition of music needs to be allowed to expand? ${ }^{33}$

The combination and confusion of the traditional categories of composition, performance, and interpretation, subverts traditional musical roles and categories that are the foundation of our musical culture and thus determine the activities of music institutions, intellectual property law, music education, etc. Composer-performers of interdisciplinary work fall in between categories and thus in between institutions and funds, and they find that this situation has negative consequences for them with regard to both funding and institutional support. ${ }^{34}$

McCartney (1997) also found that many Canadian women composers have a multi-disciplinary approach, like Susan Frykberg, Claire Piché, Kathy Kennedy, Monique Jean, Carol Ann Weaver, Micheline Coulombe Saint-Marcoux, Diana McIntosh, Sarah Peebles, who uses the very nice term "comprovising" (133), Norma Beecroft, who says: "the categorization of music disturbs me" (35), and Marcelle Deschênes, who describes her music as "impure" (42). ${ }^{35}$ McCartney suggests that this multi-disciplinary approach can both have positive and negative consequences for funding and, hence, success. She remarks about Norma Beecroft, Micheline Coulombe Saint-Marcoux, Marcelle Deschênes and Diana McIntosh:

Yet despite their important contributions to Canadian music, these composers are rarely recognized in international publications, and are often merely given a sentence or two within Canadian histories. Perhaps this is partly because multi-disciplinary forms confound the categories of music. (McCartney 1997, 42)

But, on the other hand, McCartney reports that: "Several of the Québec composers say that difficulty getting commissions is one of the reasons that Québec women composers are so active in multimedia work." $(1997,103)$ For Monique Jean, collaboration is a positive strategy:

33 Personal correspondence, e-mail, July 20, 2005.

34 Alison Isadora remarked this in the meeting on women and music technology, organized by Stichting Vrouw en Muziek and NEAR / MuziekGroep Nederland (Hannah Bosma) in Amsterdam February 13, 2004. Also Luc Houtkamp, who composes, improvises and performs, often in collaboration with other musicians, and also creates computer programs for live electronics in an experimental musical style, reported this to me in a conversation on February 16, 2005. The fact that he had just won a prestigious prize (the VPRO / Boy Edgar Award) both underlines and undermines this somewhat. Remarkably, not only does Houtkamp's musical identity cross boundaries, but on the "live-journal" of his website, he openly writes about his bisexuality (<http://www.luchoutkamp.nl/>, <http://www.livejournal. com/users/luchout/>, accessed July 15, 2005).

35 Both Grigsby (1984) and Hinkle-Turner (2006) have found that many women composers of electroacoustic music in the United States combine electronics with other media in a multi-disciplinary practice. 
While pursuing her personal experimentation, she has developed this aesthetic by association with artists working in other disciplines to map various types of performance venues, thus increasing the accessibility of this music, which is often confined to a highly specialized network for knowledgeable music-lovers. (artist statement of Monique Jean in McCartney 1996, 38; McCartney 1997, 161).

Interdisciplinary work risks being neglected, but it may also open new possibilities for reaching an audience outside the small electroacoustic community.

One explanation of women's preference for interdisciplinarity ${ }^{36}$ is that women often come from feminine-gendered domains, such as performance, before they enter the masculine-gendered field of electroacoustic composition. Because of the masculine connotations attached to composing and technology, girls are seldom interested in electroacoustic music composition at a young age. ${ }^{37}$ Women composer-performers have developed their compositional activities later, yet retain their affiliation to singing or instrumental performance. Hinkle-Turner argues that MIDI-technology especially offered opportunities for women instrumentalists to become composer-performers:

[MIDI technology] brought an extraordinary amount of power and possibility to women musicians especially those who began their musical careers as performers of "traditionally female instruments" such as the piano and the harp and to a lesser extent, the flute and the violin. For example, once an accomplished pianist such as Sorrel Hays is able to trigger unique electronically-created sounds with her instrument the next logical curious step she can take is to explore making those sounds herself rather than simply performing sounds created by others. The women emerging as electroacoustic music composers [since the 1980s] still include several vocalists but also violinists, harpists, and wind instrument players." 38 (122)

Another explanation for women's interdisciplinary work may be found in the feminine field of "women enabling" (Green 1997, 47-50): for a long time, women have been active in occupations that enable others to make music, such as music education or the organization of music salons in the $19^{\text {th }}$ century. Working with other disciplines often involves collaboration, as Pril Smiley points out when she compares her work for theatre music with her purely electroacoustic work: "[...] theatre music can involve a very exhilarating collaborative creative effort

${ }^{36}$ Of course, considering interdisciplinarity as a feature of women's music does not mean that there are no men who do interdisciplinary work; there are many men whose work is interdisciplinary and they may encounter similar problems. In the Kraakgeluiden concert series for mixed media electroacoustic improvisation, in $200018 \%$ and in $200123 \%$ of the participating musicians were women (Metzelaar 2004). But this is still much more than the share of women in Dutch "pure" tape music: at the festival for Dutch tape music De Verborgen Planeet (June 3, 4, 52005 at NDSM in Amsterdam), organized by Stichting Panakoustikon, there was only one tape composition by a female composer in a program of more than forty compositions; see <http://www.deverborgenplaneet.nl/>.

${ }^{37}$ Metzelaar (2004) argues that a lack of role models and a lagging development of self-esteem are also causes for the later entrance of women into electroacoustic improvisation.

${ }_{38}$ However, Sorrel (Doris) Hays already composed electroacoustic music with tape, sound modification and musique concrète techniques since 1969, that is, well before the advent of MIDI (Grigsby 1984, 157; Hinkle-Turner 2006, 51). 
(the sum of individuals involved equaling more than the parts); 'straight' electronic works exemplify a very personal and individual expression [...]." (Quoted in Grigsby 1984: 170) Interdisciplinary work involves cooperation, coordination, and co-authorship, it consists of creating as well as enabling, as opposed to the "masculine" solitary act of the autonomous composer. ${ }^{39}$

\section{DOCUMENTATION/ÉCRITURE OF INTERDISCIPLINARY MUSIC}

Interdisciplinary musical works pose ontological and practical problems of documentation and publication. Interdisciplinary music is not notated in conventional scores; an intermedia composition cannot adequately be captured on a single recording medium. Unlike traditional opera, in contemporary interdisciplinary music there is no clear division between music, text, performance, and stage direction, and technology and new media are also involved. Often, the few performances of such works are the only forms in which these works exist. Singularity of time and place and the presence of the author may be essential features of such works. There may also be an ideology of presence, of the uniqueness, fullness, and essence of the here and now. It could be that the cooperation of a specific group of people in the making and the performance of the piece is essential: then the piece/performance belongs to these people and may not be done by others. The situation of the piece may be essential: it may be created for a specific occasion, time, and place. But the absence of an adequate representation of the work and the impossibility to repeat or reproduce it may also have more practical causes: documenting the work in an adequate way may cost too much time and money, and the composer may be more interested in a new project than in documenting an old work which perhaps will never be performed again anyway. Some women have also suggested that they might be scared to put their work in a fixed form, because it is more definitive and more assailable than a fleeting, one time performance. An ideological preference for the open, unfixed, one-off character of a musical performance work may go together with a fear of fixation, as Helen Hall implies: "One of the limitations of tape music, or electronic music, is the fact that it's frozen in time. Tape music, once it's done, it's done. It's a scary thing, because it never changes." (McCartney 1997, 66)

However, lack of documentation has serious disadvantages. An undocumented work is only known by its few performances. There is a lack of access to many works of the (quite recent) past, and no possibility for more intense scrutiny than that of the fleeting moment. Without some representation or reproduction, it is not possible to analyze such pieces in depth; without a form of publication that is accessible beyond a limited scope of time and place, it is not possible to develop a critical discourse, a history, and a canon. It is not accidental that McCartney chose to analyze only the tape part of the multimedia performance work Woman and House by Susan Frykberg: "I chose the 'TV song' because [...]

39 The focus of the conference "In and out of the studio" (July 25-29 2005, Concordia University, Montréal) on the broad category of women sound producers, implies a criticism of the centrality of the composer (author) and the composition (musical work) in traditional musicology. 
it is also one of the few aspects of the piece that does not change as a result of a specific performance." $(1997,216)$

For interdisciplinary musical forms, there is no status quo of documentation and publication such as the conventional score or the stereo sound recording. A score, book, article, CD, or DVD may document an aspect of an interdisciplinary work, but not the whole work. To tackle this problem, I set up a project ${ }^{40}$ on the documentation and publication of interdisciplinary music at NEAR/Donemus. ${ }^{41}$ While this project is not explicitly concerned with gender, by focusing on interdisciplinary electroacoustic music, more music by women composers comes into view than when publishing pure tape music-at least, this is the case in the Netherlands; in 2005-2006, the students worked on Anne La Berge's Drive (2003). I argue for "extended score documentation," which defines the musical work and provides sufficient information and material to make multiple performances of the musical work possible without the presence of the composer; thus it makes possible the preservation and availability of the musical work. The extended score documentation of electroacoustic compositions stretches the concept of the score and articulates new forms of the work-concept: not as one fixed object, but as a cluster of versions for different media and different situations, of which the determination or openness is well defined in the extended score documentation. ${ }^{42}$

It may seem impossible to make a satisfying documentation of an interdisciplinary performance work, when such a work essentially exists at the unique moment of its performance. Indeed, performance artists sometimes object to fixed forms like recordings. But such a binary opposition between "full" live momentary presences versus "dead" derivative fixed forms comes with an ideology of presence that was criticized by Jacques Derrida in favor of écriture. Multimedia documentation opens up possibilities for re-interpretation and dissemination. Written texts, scores or recordings can be performed, re-used and re-interpreted in various ways and in different circumstances, away from the author, and are thus always differing, partial, and changing. Instead of subscribing to an ideology of presence of the one-off performance, I prefer, from both a deconstructionist and a pragmatic standpoint, to find new ways of documenting interdisciplinary music.

It is important for women to develop alternative practices, but to avoid marginalization. A remarkable example of such a dual strategy is the work of John

40 This consists of a project for graduate students of the Professional School of Arts Utrecht, 2005-2006. The PSAU is a graduate program of Utrecht University and the Hogeschool voor de Kunsten Utrecht, in which interdisciplinary groups of students work on projects of art and media institutions. Hans Timmermans (HKU) is the main tutor for this project, which is combined with the program of the Masters of Arts in European Media (EMMA). See <http://www.psau.nl/>, <http://www.near.nl/> and Bosma (2005). I will also extend the project at NEAR/Donemus in other ways.

${ }^{41}$ Donemus is a Music Information Centre and non-profit publishing house for Dutch contemporary composed art music. I work part-time for its program NEAR (Dutch electroacoustic music). See $<$ http://www.donemus.nl/> and <http://www.near.nl/>.

${ }_{42}$ However, there are also limits to such documentation: additional documentation, of specific performances, musical practices or musical instruments, may be desirable as well; and it may not be possible to document all aspects. See Bosma (2005). 
Cage: with his radical critique of fundamental notions of Western art music he stretched the concept of the musical work enormously, but he didn't abandon it: "Cage (not unwittingly I believe) speaks of having argued himself in theory out of a career which in practice he strives to maintain." (Goehr 1992, 261) Remarkably, Cage published his compositions as scores at the major music publishing house Edition Peters, including his "silent" piece 4'33" (1952). His adherence to the concepts of the musical work and the musical score may have had an important positive influence on his career and on the canonization of his work. "Contrary to the spirit of an anti-survivalist aesthetic, in which music is performed for the present and is not composed to last, Cage's 'works' have survived and have come to be representative, no less, of the avant-garde repertoire of musical works." (Goehr 1992, 265) As Lydia Goehr shows, the work-concept is a very strong and flexible force in our musical culture.

\section{In AND Out of the Sound Studio, In and Out of Gender}

In the search for a specific women's electroacoustic music, one may discern different levels:

1) The desire of a woman composer to practice her own (woman's) style of composing within a male-dominated tradition and environment.

2) The search for empirical differences between the music of male and female composers, and for empirical similarities among works by female composers.

3) The desire of a listener/critic/scholar to find feminine, feminist or womanly features in music by women composers.

Some women composers more or less explicitly develop a specific, personal way of working as a woman in a male-dominated domain, and some make references to feminine or feminist issues in their work. However, since composition and technology are both delineated as masculine, women's electroacoustic composition is never purely feminine. In various ways, women's music involves a recombination, integration or deconstruction of feminine and masculine practices and disperses gendered binary opposites.

There is a great diversity of electroacoustic music composed by women. Some recurring features can be discerned, such as extra-musical references by way of recorded sound, text, theatre, or video; but such features can be found in music by male composers too. However, what defines the search for common characteristics in women's electroacoustic music is a desire to find feminine or feminist features in the music. This is an interpretative gesture. Distinguishing stereotypical feminine or masculine characteristics incurs the risk of reinforcing these stereotypes and of overlooking those aspects which do not conform; but one can also use such stereotypes in a critical analysis or in a revaluation of femininity. I prefer to avoid the use of metaphorical gender stereotypes, such as women's music as "soft", "cyclic," or "non-verbal", and to take into account the differences in music by women composers. A useful analysis of women's music takes as a point of departure the explicit references to women's issues in texts, images, or sounds. And like McCartney (1997), one may focus on the unsettling of binary dichotomies in a search for feminist cyborg music. 
From a listener's standpoint, following Barthes' "Death of the Author" (1977/1968), one may disregard both the intentions and the gender of the composer. But this could result in further neglect of music by women composers. I propose to consider the composer not as an authority, but as an analytical category and a feature of a musical work. ${ }^{43}$ Traditionally, composing, improvising, and technology are male-gendered domains, while singing and performing specific solo instruments are gendered as feminine. Women composer-performers disrupt this stereotypical dichotomy. The traditional notion of authorship may also collapse through women's preference for interdisciplinary work and collaboration: then authorship may be shared among several artists and the traditional roles of composer and performer are unsettled. A risk of such interdisciplinary work is that it might fall into the gaps of oblivion in between established categories, with negative implications for funding, career opportunities, artistic survival, and canonization.

"Moi je fais de la musique de femme, et lui il parle de l'universel. Why is that?" (Monique Jean in McCartney 1996, 39; 1997, 163). To avoid marginalization, it is important for women to relate to issues that are gendered, abstracted from gender, and "universal," and to form alliances in and out of gender. Women's music can be related to many issues beyond gender, such as the relation composer-performer-listener. The documentation of interdisciplinary electroacoustic music is another example of such an issue with specific importance for women's music, but also relevant to both men and women. Such documentation opens possibilities for re-interpretation and dissemination, so that interdisciplinary electroacoustic music may live on in new ways.

\section{REFERENCE LIST}

Abbate, Carolyn. 1993. "Opera; or, the Envoicing of Women". In Musicology and Difference: Gender and Sexuality in Music Scholarship, ed. Ruth Solie, 225258. Berkeley: University of California Press.

Barthes, Roland. 1977 (1968). "The Death of the Author". In Image / Music / Text, ed. and trans. Stephen Heath, 142-147. New York: Hill and Wang.

Berio, Luciano. 1959. "Musik und Dichtung-eine Erfahrung", Darmstädter Beiträge zur neuen Musik 1959: 36-45.

- 2000 (1959). "Poetry and Music-an Experience" / "Poesia e musicaunesperienza". Trans. Alessandra Petrina. In New Music on the Radio: Experiences at the Studio di Fonologia of the RAI, Milan 1954-1959 / Nuova Musica alla Radio: Esperienze allo Studio di Fonologia della RAI di Milano 1954-1959., ed. Veniero Rizzardi and Angela Ida De Benedictis, 236-259. Italy: CIDIM.

Bosma, Hannah. 1996a. "Authorship and Female Voices in Electrovocal Music". Poster at the International Computer Music Conference 1996, Hong Kong: International Computer Music Association / Hong Kong University of Science and Technology.

${ }^{43}$ See Foucault 1977/1969. 
1997. "Écriture féminine in Electrovocal Music". Paper presented at the Feminist Theory and Music 4 conference, University of Virginia, Charlottesville, VA, USA.

- 1998a. "Who Makes Electronic Music? Vocalists, composers, gender and electronic music technology", Switch 4, Internet publication at $<\mathrm{http}: / /$ switch.sjsu.edu/nextswitch/switch_engine/front/front.php?artc=155>. San Francisco: CADRE Institute, San Jose State University.

— 1998b. "Death of the Singer: Authorship and Female Voices in Electronic Music." eContact! 1.3. Internet publication at <http://cec.concordia. ca/econtact/>, Montreal: Canadian Electroacoustic Community.

_ 1998c. "Gender and Electroacoustics". eContact! 1.1. Internet publication $<$ http://cec.concordia.ca/econtact/>, Montreal: Canadian Electroacoustic Community.

-2000. "Who Creates Electro-Vocal Music? (authors, composers, vocalists and gender)" In Ctrl+Shift Art - Ctrl+Shift Gender. Amsterdam: Axis v/m.

_. 2003. "Bodies of Evidence, Singing Cyborgs and Other Gender Issues in Electrovocal Music". Organised Sound 8/1: 5-17.

- 2005. "Documentation and Publication of Electroacoustic and Multimedia Compositions at NEAR: Experiences and Experiments", Electroacoustic Music Studies network 05, <http://www.ems-network.org> (October 22, 2005). An updated version (2006) of the extended paper is available via $<$ http://www.near.nl/ $>$.

- 2006. "Thema (Omaggio a Joyce): A Listening Experience as Homage to Cathy Berberian." Paper presented at the conference Cathy Berberian: Pioneer of Contemporary Vocality and Performance, University of Amsterdam, April 27, 2006.

Braidotti, Rosi. 1990. Beelden van de leegte: Vrouwen in de hedendaagse filosofie. Trans. Ineke van den Burg. Kampen: Kok Agora.

Citron, Marcia J. 1993. Gender and the Musical Canon. Cambridge: Cambridge University Press.

Cox, Renée. 1991. "Recovering Jouissance: An Introduction to Feminist Musical Aesthetics". In Women and Music: A History, ed. Karin Pendle, 331-340. Bloomington: Indiana University Press, 1991.

Cusick, Suzanne G. 1999. "On Musical Performances of Gender and Sex". In Audible traces-gender, identity, and music, ed. Elaine Barkin and Lydia Hamessley, 25-48. Zürich: Carciofoli.

Dame, Joke. 1994. Het zingend lichaam: Betekenissen van de stem in westerse vocale muziek. Kampen: Kok Agora.

Dreßen, Norbert. 1982. Sprache und Musik bei Luciano Berio: Untersuchungen zu seinen Vokalkompositionen. Regensburg: Gustav Bosse Verlag.

Foucault, Michel. 1977 (1969). "What is an Author?" in: Language, Countermemory, Practice: Selected Essays and Interviews, ed. Donald F. Bouchard, trans. by Donald F. Bouchard and Sherry Simon. Oxford: Blackwell.

Goehr, Lydia. 1992. The Imaginary Museum of Musical Works: An Essay in the Philosophy of Music. Oxford: Oxford University Press. 
Green, Lucy. 1997. Music, Gender, Education. Cambridge: Cambridge University Press.

Grigsby, Beverly. 1984. "Women Composers of Electronic Music in the United States". In The Musical Woman: An International Perspective, 151-196, ed. Judith Lang Zaimont e.a. Westport: Greenwood Press.

Guild, Elizabeth. 1992. "Écriture féminine." In Feminism and Psychoanalysis: A Critical Dictionary, ed. Elizabeth Wright, 74-76. Oxford: Blackwell.

Harding, Sandra. 1986. The Science Question in Feminism. Ithaca, NY: Cornell. Hinkle-Turner, Elizabeth. 2006. Women Composers and Music Technology in the United States: Crossing the Line. Aldershot: Ashgate.

McCartney, Andra. 1995. "Whose Playground, Which Games, and What Rules?: Women Composers in the Digital Playground". In: ICMC'95 Proceedings, 553-560. San Francisco: International Computer Music Association; Banff: ICMC'95.

_. 1996. "The Ambiguous Relation," Contact! Vol.9 No. 2: 29-47.

1997. Creating Worlds For My Music To Exist: How Women Composers of Electroacoustic Music Make Place For Their Voices. MA Thesis, York University, North York, Ontario.

McClary, Susan. 1991. Feminine Endings: Music, Gender, and Sexuality. Minneapolis: University of Minnesota Press.

Metzelaar, Helen. 2004. "Women and 'Kraakgeluiden': Participation of Women Improvisers in the Dutch Electronic Music Scene". Organised Sound 9/2: 199-206.

Moi, Toril. 1985. Textual/Sexual Politics: Feminist Literary Theory. London: Methuen.

Moi, Toril, ed. 1986. The Kristeva Reader. Oxford: Blackwell.

Di Scipio, Agostino. 2005. "D’une expérience en écoute de phoné et logos: Texte, son et structure dans Thema (Omaggio a Joyce) de Luciano Berio" Revue DEMéter, août 2005, Université de Lille-3. <http://www.univ-lille3.fr/ revues/demeter/analyse/discipio.pdf $>$.

Silverman, Kaja. 1988. The Acoustic Mirror: The Female Voice in Psychoanalysis and Cinema. Bloomington and Indianapolis: Indiana University Press.

Vila, Marie Christine. 2003. Cathy Berberian: Cant'actrice. Paris: Fayard.

Weber-Lucks, Theda. 2003. "Electroacoustic Voices in Vocal Performance Arta Gender Issue?” Organised Sound 8/1: 61-69.

\section{Abstract}

This essay explores the possibilities and limitations of an écriture féminine musicale in electroacoustic music. Theories by Cox, Dame, and Citron about "women's music" are discussed alongside research on women electroacoustic composers by McCartney and Hinkle-Turner, and analyses of works by Rudow, Isadora, and LaBerge. The operation of gendered musical categories is analysed in the appropriation of Cathy Berberian's "voice" by Berio. Strategies for destabilizing historically gendered categories in music are discussed, including feminine/feminist content, composer-performers, interdisciplinarity, and col- 
laboration. The interdisciplinary character of many women's work may hamper its documentation and thus its survival. The author's research at NEAR/Donemus focuses on this problem.

\section{RÉSUMÉ}

Cet essai explore les possibilités et limites d'une écriture féminine musicale dans la musique électroacoustique. Les théories de Cox, Dame et Citron sur la « musique des femmes " sont discutés en parallèle avec les travaux de McCartney et Hinkle-Turner sur les compositrices électroacoustiques et les analyses d’œuvres de Rudow, Isadora et LaBerge. Létablissement de rapports sociaux de genres pour les catégories musicales est analysé par l'exemple de lopération d'appropriation de la " voix " de Cathy Berberian par Berio. Des stratégies de déstabilisation de catégories musicales sexuées sont ici étudiées, par exemple le contenu féminin/féministe, les compositrices/interprètes, l'interdisciplinarité et la collaboration. Le caractère interdisciplinaire de plusieurs œuvres de femmes peut entraver sa documentation et, de ce fait, sa pérennité. La recherche de l'auteure, réalisée à NEAR/Donemus, porte spécialement sur ce problème. 